\title{
Haemato-biochemical profiles of indigenous goats (Capra hircus) at Chittagong, Bangladesh
}

\author{
Amir Hossan Shaikat ${ }^{1}$, Mohammad Mahmudul Hassan ${ }^{1}$, Shahneaz Ali Khan $^{1}$, Md. Nurul Islam ${ }^{1}$, Md. Ahasanul Hoque ${ }^{1}$, \\ Md. Saiful Bari' ${ }^{2}$ and Md. Emran Hossain ${ }^{3}$
}

1. Department of Physiology, Biochemistry and Pharmacology, Faculty of Veterinary Medicine, Chittagong Veterinary and Animal Sciences University, Khulshi, Chittagong-4202, Bangladesh; 2. Department of Dairy and Poultry Science, Faculty of Veterinary Medicine, Chittagong Veterinary and Animal Sciences University, Khulshi, Chittagong-4202, Bangladesh; 3. Department of Animal Science and Nutrition, Chittagong Veterinary and Animal Sciences University, Khulshi, Chittagong-4202, Bangladesh

Corresponding author: Mohammad Mahmudul Hassan, email: miladhasan@yahoo.com, Cell: +88-01554326951 Received: 04-05-2013, Revised: 15-07-2013, Accepted: 16-07-2013, Published online: 27-08-2013

doi: 10.14202 /vetworld.2013.789-793

How to cite this article: Shaikat AH, Hassan MM, Khan SA, Islam MN, Hoque MA, Bari MS and Hossain ME (2013) Haematobiochemical profiles of indigenous goats (Capra hircus) at Chittagong, Bangladesh, Veterinary World 6(10): $789-793$.

\begin{abstract}
Aim: A 6 month long study was undertaken to determine various hemato-biochemical profiles of indigenous goats (Capra hircus) in Bangladesh.

Materials and methods: Blood samples were collected from goats of different ages of 5 Upazilla of Chittagong. A total of 120 goats (60 Black Bengal and 60 Jamnapari) having $\geq 6$ months of age were included. The whole blood was analyzed for hematology, and plasma and serum samples for biochemical analysis.

Results: The study found higher number of RBC (million/cumm) and PCV\% in the goats of age 48 months and above (18.23 \pm 1.89 and $28 \pm 3.2)$ respectively. Besides, total protein was found higher $(78.9 \pm 14.5 \mathrm{~g} / \mathrm{L})$ in the goats of $6-24$ months of age. Significant increase $(p<0.01)$ of the number of WBC (thousand/cumm), RBC (million/cumm), PCV\% was observed in Black Bengal over Jamnapari goat. In contrast, WBC, lymphocytes, RBC, PCV, ALT, and AST were significantly $(p<0.01)$ higher in Black Bengal than Jamnapari goat; whereas, monocyte, TP, Albumin, and Urea levels were significantly $(p<0.01)$ higher in Jamnapari than Black Bengal goats.
\end{abstract}

Conclusion: The results of the present study demonstrate the normal haemato-biochemical values of two local goat breeds. Present results stated some significant variation of parameters between two goats whereas some shows no significant variation at all.

Keywords: biochemistry, hematology, indigenous goats

\section{I ntroduction}

Livestock has been an important component of mixed farming system practiced in Bangladesh. The magnitude of contribution of the livestock sub-sector to the GDP is about $6.5 \%$ in Bangladesh. There are about 22.87 million cattle, 20.75 million goats and 2.68 million sheep in this country [1]. The goat secures second position in terms of meat, milk, and skin production representing about $38.0 \%, 23.0 \%$ and $28.0 \%$, respectively to the total contribution of livestock in Bangladesh [2]. Goat rearing is one of the most important sources of income for majority of rural families in Bangladesh. The Black Bengal goats are dwarf goats and are known to be famous for its adaptability, fertility, fecundity, delicious meat, superior skin, extreme disease resistance and wide range of acceptability under adverse agro-climatic condition [3]. Higher reproductive efficiency, better capacity to subsist on harsh nutritional regime and low risk of death make a viable proposition for increasing the productivity of goats $[4,5]$. The significance of

Copyright: The authors. This article is an open access article licensed under the terms of the Creative Commons Attribution License (http://creativecommons.org/licenses/by/2.0) which permits unrestricted use, distribution and reproduction in any medium, provided the work is properly cited. determining haematological and biochemical indices of domestic animals has been well documented [6] and the changes of these parameters have been studied in cattle [7], sheep [8] and goats $[9,10]$. There is a great variation in the haematological and biochemical parameters as observed between breeds of goats [9] and in this regard it may be difficult to formulate a universal metabolic profile test for goats.

The hematological and biochemical values are very important for evaluation of normal physiological status of animal. However, no or very few works has been undertaken in relation with indigenous Black Bengal and Jamnapari goat. The differences has further under lined the need to establish an appropriate physiological baseline values for various breeds of livestock in Bangladesh which will help in realistic evaluation of the management practices, nutritional and diagnosis of health conditions. These variations also limit the effort of animal scientist to come up with a uniform test for indigenous Bangladeshi goat breeds. These variations lead to the need for the establishment of a discrete and direct baseline values for various goat breeds of Bangladesh.

Therefore, we aim to investigate on the baseline haematological and biochemical data of goats breed 
Table-1. Hematological status of Black Bengal and Jamnapari goats

\begin{tabular}{llll}
\hline Age (months) & Parameter & Mean \pm SD & Range \\
\hline $6-24$ & RBC (million/cumm) & $12.04 \pm 4.23$ & $8.02-17.05$ \\
$(\mathrm{n}=40)$ & WBC (thousand/cumm) & $6.75 \pm 4.77$ & $2.5-14.2$ \\
& Lymphocyte (\%) & $17.21 \pm 4.69$ & $1.6-38$ \\
& Monocyte (\%) & $5.12 \pm 3.7$ & $0.4-10.6$ \\
& Granulocyte (\%) & $77.64 \pm 17.92$ & $51.4-99$ \\
& Hemoglobin (g/dl) & $5.21 \pm 1.03$ & $3.6-6.6$ \\
& PCV (\%) & $22 \pm 3.2$ & $18-27.2$ \\
& MCV & $36.27 \pm 0.96$ & $33-37$ \\
$24-48$ & RBC (million/cumm) & $16.45 \pm 2.13$ & $14.23-18.34$ \\
$(\mathrm{n}=40)$ & WBC (thousand/cumm) & $9.55 \pm 3.29$ & $6.2-12.9$ \\
& Lymphocyte (\%) & $27.32 \pm 4.51$ & $15.2-51.2$ \\
& Monocyte (\%) & $3.87 \pm 0.57$ & $2.9-4.3$ \\
& Granulocyte (\%) & $69.32 \pm 15.01$ & $44.6-81.7$ \\
& Hemoglobin (g/dl) & $5.77 \pm 0.43$ & $5.3-6.2$ \\
& PCV (\%) & $24.1 \pm 4.2$ & $19.3-28.5$ \\
& MCV & $36 \pm 1.89$ & $34-39$ \\
$48-$ above & RBC (million/cumm) & $18.23 \pm 3.67$ & $14.75-22.34$ \\
$(\mathrm{n}=40)$ & WBC (thousand/cumm) & $14.19 \pm 8.76$ & $6.5-28.4$ \\
& Lymphocyte (\%) & $23.25 \pm 10.43$ & $10.3-38.5$ \\
& Monocyte (\%) & $7.5 \pm 2.47$ & $4.2-10.6$ \\
& Granulocyte (\%) & $69.52 \pm 9.85$ & $57.3-83.4$ \\
& Hemoglobin (g/dl) & $7.3 \pm 1.44$ & $5.2-9.2$ \\
& PCV (\%) & $28.3 \pm 3.2$ & $24.5-30.4$ \\
& MCV & $36.0 \pm 1.47$ & $33-39$ \\
\hline
\end{tabular}

raised under native husbandry practices in Bangladesh as influenced by breed, sex and age on which little or no work was done on it. Considering these facts, the present study was undertaken to find out the normal hematological and biochemical values of Black Bengal and Jamnapari goat and to use it as a base or platform for further study.

\section{Materials and Methods}

Study area: This study was undertaken at periphery of Chittagong municipality under Pahartali, Raozan, Bashkhali, Satkania and Sitakunda Upazilla. The availability of goat population and easy communication were taken into consideration for the present study. Mixed family farming consisting of 1 to 2 cattle, goat or sheep and few poultry was practiced as farming system in these areas.

Study population, period and design: Black Bengal and Jamnapari goats, very much adaptable to Bangladesh, were chosen to investigate haemato-biochemical parameters during July to December, 2011.

A total of 120 goats consisting 60 Black Bengal and 60 Jamnapari goats were selected randomly from a complete list of goats in the study area. Equal number of apparently healthy male and female goats having $\geq 6$ months of age was fixed as an inclusion criterion. Approximately, $5 \mathrm{ml}$ of blood per goats was drawn aseptically from Jugular vein, of which $3 \mathrm{ml}$ of blood was transferred to a sterile vial containing disodium EDTA $(1 \mathrm{mg} / \mathrm{ml}$ of blood) in order to estimate routine blood parameters testing as per procedure published by Sharma and Singh [11]. Remaining $2 \mathrm{ml}$ of blood sample was transferred to vacutainer tube for serum separation. Serum samples obtained by centrifugation were used to determine total protein, albumin, phosphorus, urea, Alanine Transaminase (ALT) and Aspertate Amino Transferase (AST) using automatic biochemical analyzer (Humalyzer-3000, USA).

Statistical analysis: The data obtained were imported, stored and coded according to recorded information in the data sheet using the Microsoft Excel-2007 program and then exported to STATA/IC-11 (Stata Corporation College Station) for statistical analysis. A descriptive statistics was performed for haemato-biochemical parameters according to different species and age categories. The student $\mathrm{t}$-test was used to compare the results of different haemato-biochemical parameters between goat types. The results were presented as mean with the standard deviation and p-value $<0.05$ was considered significant.

\section{Results}

The hematological and biochemical values of Capra hircus (Black Bengal and Jamnapari) goat has been shown in Table-1. The observed hematological value showed significant increase in RBC, WBC, PCV\% ( $p<0.01)$ in Black Bengal goat than Jamnapari goat. RBC (million/cumm) was highest $(18.23 \pm 3.67)$ in 48-above months aged goat. The WBC (thousand/ cumm), Monocyte (\%), Hemoglobin (g/dl), PCV\% was also highest in the goats of 48 -above months age (Table-1).

Table-2 shows that Total protein $(\mathrm{g} / \mathrm{L})$ was highest $(78.9 \pm 14.50)$ in 6-24 months aged goat whereas albumin $(\mathrm{g} / \mathrm{L})$ and phosphorus $(\mathrm{mg} / \mathrm{dl})$ was highest in goat of 48 -above months of age. The value of urea was found highest $(35.4 \pm 10.25 \mathrm{mg} / \mathrm{dl})$ at the age group of between 24-48 months and lowest (19.60 \pm $4.01)$ was in $<24$ months of age. On the other hand, the value of ALT and AST was highest $(29.52 \pm 11.47$ and $63.65 \pm 6.68 \mathrm{U} / \mathrm{L}$ respectively) at age group 6-24 months but ALT was lowest $(15.35 \pm 2.55 \mathrm{U} / \mathrm{L})$ at age group >48 months and AST was lowest (41.62 \pm $4.56 \mathrm{U} / \mathrm{L}$ ) at age group 24-48 months. 
Table-2. Biochemical status of Black Bengal and Jamnapari goats

\begin{tabular}{llll}
\hline Age (months) & Parameter & Mean \pm SD & Range \\
\hline $6-24$ & Total protein $(\mathrm{g} / \mathrm{L})$ & $78.9 \pm 14.50$ & $62.9-100.5$ \\
$(\mathrm{n}=40)$ & Albumin $(\mathrm{g} / \mathrm{L})$ & $46.65 \pm 10.25$ & $32.5-60.1$ \\
& Phosphorus $(\mathrm{mg} / \mathrm{dl})$ & $2.55 \pm 1.06$ & $1.6-4.3$ \\
& Urea $(\mathrm{mg} / \mathrm{dl})$ & $19.60 \pm 4.01$ & $13.8-23.7$ \\
& ALT $(\mathrm{U} / \mathrm{L})$ & $29.52 \pm 11.47$ & $18.7-48.2$ \\
& AST $(\mathrm{U} / \mathrm{L})$ & $63.65 \pm 6.68$ & $55.5-72.2$ \\
$24-48$ & Total protein $(\mathrm{g} / \mathrm{L})$ & $72.65 \pm 16.66$ & $56.8-100.1$ \\
$(\mathrm{n}=40)$ & Albumin $(\mathrm{g} / \mathrm{L})$ & $40.62 \pm 5.04$ & $33.4-47$ \\
& Phosphorus $(\mathrm{mg} / \mathrm{dl})$ & $2.87 \pm 1.61$ & $1.2-5.5$ \\
& Urea (mg/dl) & $35.4 \pm 10.25$ & $27.1-52.6$ \\
& ALT (U/L) & $20.35 \pm 11.33$ & $12.8-39.7$ \\
& AST $(\mathrm{U} / \mathrm{L})$ & $41.62 \pm 4.56$ & $37.4-49.1$ \\
$48-a b o v e$ & Total protein $(\mathrm{g} / \mathrm{L})$ & $71.1 \pm 3.90$ & $54.5-74$ \\
$(\mathrm{n}=40)$ & Albumin $(\mathrm{g} / \mathrm{L})$ & $48.3 \pm 8.31$ & $40.4-61.4$ \\
& Phosphorus $(\mathrm{mg} / \mathrm{dl})$ & $3.67 \pm 1.13$ & $2-5.1$ \\
& Urea $(\mathrm{mg} / \mathrm{dl})$ & $34.62 \pm 9.77$ & $21.1-48.4$ \\
& ALT $(\mathrm{U} / \mathrm{L})$ & $15.35 \pm 2.55$ & $12.4-19.3$ \\
& AST $(\mathrm{U} / \mathrm{L})$ & $55.17 \pm 16.41$ & $38-72.5$ \\
\hline
\end{tabular}

Table-3. Comparative hematological status of Black Bengal and J amnapari goat

\begin{tabular}{llllll}
\hline Parameter & Black B engal & J amnapari & t & df & p-value \\
\hline WBC (thousand/cumm) & $13.17 \pm 1.01$ & $7.15 \pm 0.44$ & 6.04 & 59 & 0.001 \\
Lymphocyte (\%) & $25.82 \pm 2.06$ & $19.36 \pm 1.42$ & 2.53 & 59 & 0.01 \\
Monocyte (\%) & $4.75 \pm 0.10$ & $6.25 \pm 0.51$ & -2.99 & 59 & 0.004 \\
Granulocyte (\%) & $69.57 \pm 1.94$ & $74.75 \pm 1.89$ & -1.83 & 59 & 0.07 \\
RBC (million/cumm) & $15.22 \pm 2.91$ & $11.21 \pm 2.4$ & -6.94 & 59 & 0.001 \\
Hb (g/dl) & $6.16 \pm 0.22$ & $6.02 \pm 0.11$ & 0.66 & 59 & 0.50 \\
PCV (\%) & $27.3 \pm 2.3$ & $24.2 \pm 3.4$ & -5.33 & 59 & 0.001 \\
MCV & $36.16 \pm 0.14$ & $36.01 \pm 0.22$ & 0.52 & 59 & 0.59 \\
\hline
\end{tabular}

Table-4. Comparative biochemical status of Black Bengal and J amnapari goat

\begin{tabular}{llllll}
\hline Parameter & Black B engal & J amnapari & t & df & p-value \\
\hline Total protein $(\mathrm{g} / \mathrm{L})$ & $69.9 \pm 1.03$ & $78.53 \pm 2.05$ & 3.04 & 59 & 0.0035 \\
Albumin $(\mathrm{g} / \mathrm{L})$ & $43.01 \pm 0.75$ & $47.36 \pm 1.35$ & 2.87 & 59 & 0.0057 \\
Phosphorus $(\mathrm{mg} / \mathrm{dl})$ & $3 \pm 0.17$ & $3.06 \pm 1.17$ & 0.22 & 59 & 0.82 \\
Urea (mg/dl) & $23.90 \pm 0.89$ & $35.85 \pm 1.47$ & 8.72 & 59 & 0.001 \\
ALT (U/L) & $26.15 \pm 1.72$ & $17.33 \pm 0.69$ & 4.95 & 59 & 0.001 \\
AST (U/L) & $59.8 \pm 2$ & $47.16 \pm 1.05$ & 5.87 & 59 & 0.001 \\
\hline
\end{tabular}
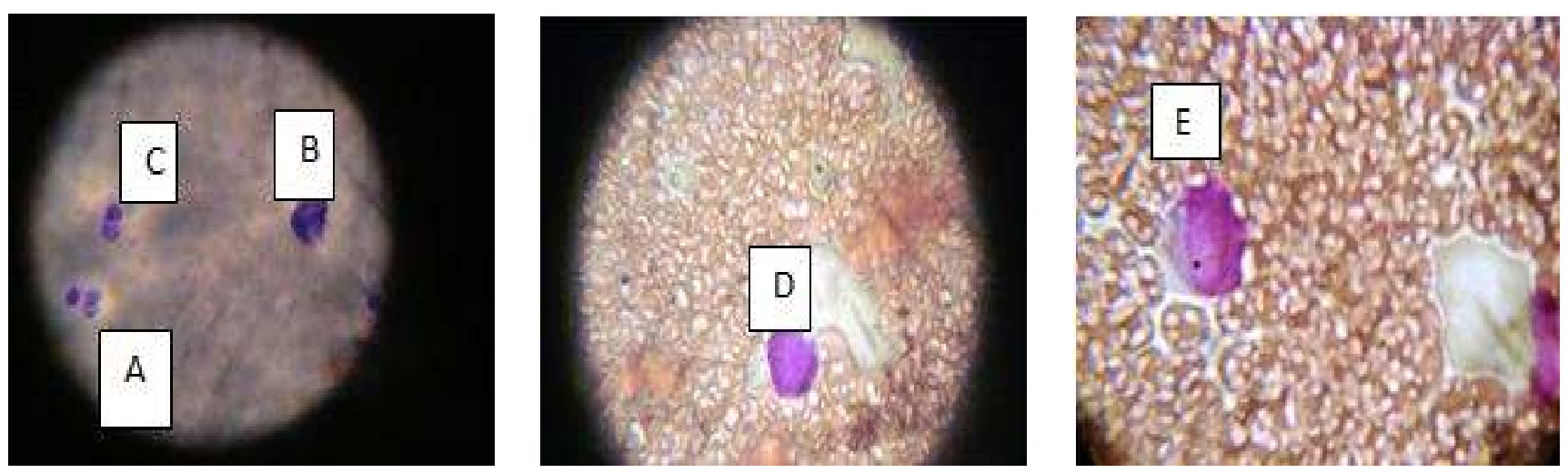

Figure. Differential leucocytes A. Neutrophil, B. Basophil, C. Eosinophil D. Lymphocyte, E. Monocyte

Table-3 and 4 shows that, among various haematological parameters, WBC, lymphocyte, PCV, RBC were significantly $(p<0.01)$ higher in Black Bengal goats than Jamnapari; whereas, monocyte was significantly $(p<0.01)$ higher in Jamnapari than Black Bengal goats. with regard to biochemical parameters, total protein, albumin, urea were significantly $(p<0.01)$ higher in Jamnapari than Black Bengal goats. However, ALT and AST value was significantly $(p<0.01)$ higher in Black Bengal goats than Jamnapari goats. Granulocyte, $\mathrm{Hb}, \mathrm{MCV}$ and phosphorus values were not significantly $(p>0.01)$ varied between Black
Bengal and Jamnapari goats.

\section{Discussion}

According to the current study, the hematological and biochemistry values of Black Bengal goat and Jamnapari goat were found within the normal ranges. These results are supported by the Kaneko et al., [12]. The present finding of the number of RBC (million/cumm) of kids (6-24 months of age) is agreed by Zumbo et al., [13]. The number of WBC (million/cumm) of kids (6-24 months) in the present study was lower than the result of Zumbo et al., [13]. It 
might be due to difference in the rate of infection and immunological response. In this study, the kids possesses less hemoglobin content $(\mathrm{gm} / \mathrm{dl})$ than the result of the study conducted by Zumbo et al., [13]. The $\mathrm{MCV}$ value of the current study was very much higher than the study on kids MCV observed by Zumbo et al., [13]. However, there was no significant variation in haematological parameters of dogs among the age groups except RBC [14].

The number of RBC (cumm) in the current study does not agreed by Rice and Hall, [15] who conducted similar study on mountain goats. It might be due to variation in magnitude of their position. In the present study, the number of WBC was higher than the finding of Rice and Hall, [15] and Piccione et al., [16]. It might be due to frequency of exposure of different pathogens and other environmental factors. The $\mathrm{Hb}$ contents (gm/dl) of the study conducted by Rice and Hall, [15] and Piccione et al., [16] on Girgentana goats were higher than the present findings. The hemoglobin content $(\mathrm{gm} / \mathrm{dl})$ in the present finding was agreed by Kiran et al. [17]. It might be due to nutritional variation of these two kinds of goats. The result of MCV content was nearer to Rice and Hall, [15] study. In the present study the lymphocyte percentage was lower than the findings of Rice and Hall, [15] for mountain goats but higher than Piccione et al., [16]. It may be due to altitude variation and other factors. The monocyte percentage of adult goats was higher in the present study than the findings of Rice and Hall, [15] for mountain goats \& Piccione et al., [16] for Girgentana goat. It might be due to more prevalence of exposure of chronic infection in plain land than those of mountain. The haemato-biochemical parameters also varied sometimes based on management practices and nutritional status in chicken [18] and production stages of ducks [19].

In the present study, the total protein content $(\mathrm{gm} / \mathrm{dl})$, albumin and urea $(\mathrm{mg} / \mathrm{dl})$ were significantly higher than the observed result but the phosphorous content ( $\mathrm{mg} / \mathrm{dl})$ was lower than the result observed by Rice and Hall, [15]. It might be due to difference in feed intake \& nutritional difference between the goats of the two studies. In the present study the RBC content (million/cumm) was higher than the findings of Piccione et al., [16] of the same age group ( $>4$ years). It might be due to geographical variation.

Significant $(p<0.01)$ variation was observed in WBC, lymphocytes, monocyte, RBC, PCV, total protein, albumin, urea, ALT and AST between the Black Bengal and Jamnapari goats in the present study. This statement partially support by Addass et al., [20] who observed haemato-biochemical findings of indigenous goats in Nigeria.

\section{Conclusion}

Present study represents the normal values of haemato-biochemical parameters of two indigenous goat breeds of Bangladesh, Black Bengal and Jamnapari.
The study results show the significant variation in some of the haemato-biochemical parameters. Moreover, variation was also observed based on sex and age. However, further investigation is required to verify the values depending on seasons and other climatic conditions. Intensive studies on all the haematobiochemical parameters with some micro-minerals were needed to establish a final reference values.

\section{Authors' contributions}

MMH and AHS implemented the study design and carried out the laboratory experimentation. $\mathrm{MMH}$, SAK, MNI, MEH, MAH and MSB drafted and revised the manuscript. All authors read and approved the final version of manuscript.

\section{Acknowledgements}

Authors are grateful to the University Grants Commission (UGC) of Bangladesh (grant no. 14/2011) for providing financial support to the present research project.

\section{Competing interests}

The authors declare that they havenocompeting interests.

\section{References}

1. Department of Livestock Services (2007) Livestiock \& Poultry population in Bangladesh. http://www.dls.gov.bd. Accessed on 03-03-2013.

2. Devendra, C. (2007) Perspectives on animal production systems in Asia. Livest. Sci., 106: 1-18.

3. FAO (Food and Agricultural Organization of the United Nations). (2008). FAOSTAT http://faostat.fao.org/ default. aspx. Accessed on 03-03-2013.

4. Hassan, M. M., Mahmud, S. M. N., Islam, S. K. and Miazi, O. F. (2007) A comparative study on reproductive performance and productivity of Black Bengal and Crossbred goat at Atrai, Bangladesh. Univ. J. Zool. Rajshahi Univ., 26: 55-57.

5. Hassan, M.M., Hoque, M.A., Islam, S.K.M.A., Khan, S.A., Roy, K. and Banu, Q. (2011) A prevalence of parasites in black Bengal goats in Chittagong, Bangladesh. Int. J. Livest. Prod., 2 (4): 40-44.

6. Babeker, E.A. and Elmansoury, Y.H.A. (2013) Observations concerning haematological profile and certain biochemical in Sudanese desert Goat. Online J. Anim. Feed Res., 3(1):8086.

7. Obi, T.U. and Anosa, V.O. (1980) Haematological studies of Domestic Animals, I.V. Clino-haematological feature of Bovine trypanosomiasis, theileriosis, anaplaasmosis, Epertherozooniasis and helminthiasis. Zeuntral-blath Vet. Medic. Relhe., 27: 189-197.

8. Tambuwal, F. M., Agale, B. M. and Bangana, A. (2002) Hematological and biochemical values of apparently healthy Red Sokoto Goats. Proceeding of $27^{\text {th }}$ Annual Conference Nigerian society of Animal Production (NSAP), March, 1721, 2002, FUTA, Akure, Nigeria. pp. 50-53.

9. Waziri, M. A., Ribadu, A. Y. and Sivachelvan, N. (2010) Changes in the serum proteins, hematological and some serum biochemical profiles in the gestation period in the Sahel goats. Vet. Arhiv., 80(2): 215-224.

10. Hassan, M.M., Hoque, M.A., Islam, S.K.M.A., Khan, S.A., Hossain, M.B. and Banu, Q. (2012) Efficacy of anthelmintics against parasitic infections and their treatment effect on the production and blood indices in Black Bengal goats in Bangladesh. Turk. J. Vet. Anim. Sci., 36(4): 400-408.

11. Sharma, I.J. and Singh, H.S. (2000) Students Laboratory Manuals of Veterinary Physiology, $1^{\text {st }}$ edn. Kalyani Publisher, New Delhi, India. 
12. Kaneko, J.J., Harvey, J.W. and Bruss, M.L. (1997) Blood analyte reference values in large animals. Clinical biochemistry of domestic animals, Fifth edition, Delhi, India. Pp. 890-903.

13. Zumbo, A., Sciano, S., Messina, V., Casella, S., Rosa, R. and Piccione, G.(2011) Heamatological profile of messinese goat kids and their dams during the first month post- partam, Anim. Sci. Pap. Rep., 29(3): 223-230.

14. Khan, S.A., Desmond, J., Olival, K. J., Hassan, M.M., Hossain, M.B., Rahman, K.B.M.A., Elahi, M. F., Mamun, M. A., Haider, N., Yasin, G. and Epstein, J.H. (2011) Hematology and serum chemistry reference values of stray dogs in Bangladesh. Open Vet. J., 1: 13-20.

15. Rice, C. G. and Hall, B. (2007) Hematologic and Biochemical Reference Intervals for Mountain Goats (Oreamnos americanus): Effects of capture conditions, Northwest Sci., 81(3): 206-214.

16. Piccione, G., Casella, S., Lutri, L., Vazzana, I., Ferrantelli, V. and Caola, G. (2010) Reference values for some haematological, haematochemical and electrophoretic parameters in the Girgentana goat, Turk. J. Anim.Sci.,34(2):
197-204.

17. Kiran, S., Bhutta, A. M., Khan, B. A., Durrani, S., Ali, M., Ali, M. and Iqbal, F. (2012) Effect of age and gender on some blood biochemical parameters of apparently healthy small ruminants from southern Punjab in Pakistan, APJTB., 304306.

18. Islam, S.K.M.A., Alauddin, M., Hassan, M.M., Khan, S.A., Alam, M.R., Hossain, M.B., Ahasan, A.S.M.L., Saifuddin, A.K.M., Sultana, S., Tun, H.N., Shaikat, A.H., Debnath, N.C. and Hoque, M.A. (2012) A study of bio-chemical analysis on blood and crop contents of household chikens along with their production and health status in Bangladesh. Pak. Vet. J., 32(4): 575-578.

19. Khan, S.A., Alauddin, M., Hassan, M.M., Islam, S.K.M.A., Hossain, M.B., Shaikat, A.H., Islam, M.N., Debnath, N.C. and Hoque, M.A. (2013) Comparative performance and Haemato-biochemical profile of jinding ducks in different production systems of Bangladesh. Pak. Vet. J., 33(1): 113-116.

20. Addass, P.A., Midau, A. and Babale, D.M. (2010) Haematobiochemical findings of indigenous goats in Mubi Adamawa State, Nigeria. J. Agric. Soc. Sci., 6: 14-16.

$* * * * * * * *$ 